\title{
Erratum zu: Beratung und Projekte
}

\section{Kapitel 30 : F. Bertagnolli, Lean Management,}

https://doi.org/10.1007/978-3-658-31240-4_30

Die Abbildung 30.2 wurde korrigiert und muss wie folgt aussehen:

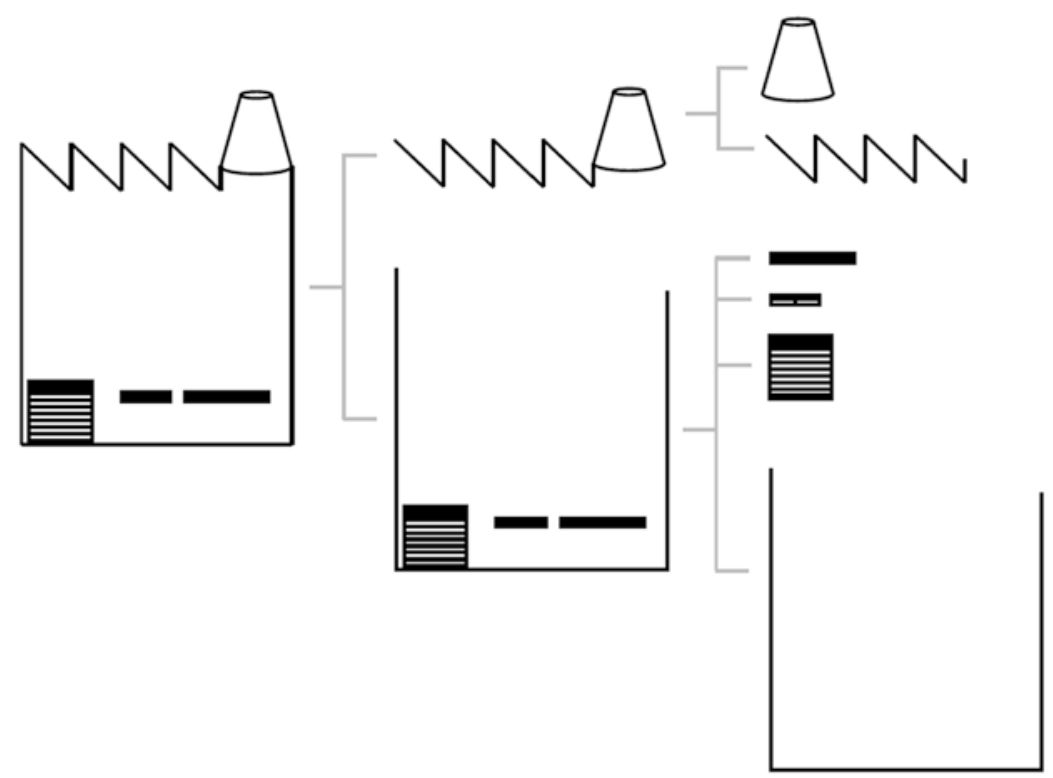

Die aktualisierte Version des Kapitels ist verfügbar unter https://doi.org/10.1007/978-3-658-31240-4_30 